\title{
Acute toxicity test of agricultural pesticides on silver catfish (Rhamdia quelen) fingerlings
}

\author{
Teste de toxicidade aguda de pesticidas agrícolas em alevinos de jundiás \\ (Rhamdia quelen) \\ Luiz Carlos Kreutz ${ }^{\mathrm{I} *}$ Leonardo José Gil Barcellos ${ }^{\mathrm{II}}$ Tális Oliveira Silva \\ Deniz Anziliero ${ }^{\mathrm{I}}$ Daiana Martins ${ }^{\mathrm{I}}$ Monique Lorenson ${ }^{\mathrm{I}}$ Ariane Marteninghe ${ }^{\mathrm{I}}$ \\ Leonardo Bolognese da Silva ${ }^{I I}$
}

\begin{abstract}
- NOTE -
\section{ABSTRACT}

Toxicity risks of agricultural pesticides to fishes are pivotal. Currently, many questions remain unsolved regarding to the toxicity of commonly used pesticides to silver catfish (Rhamdia quelen), a South American catfish. The present studies have been designed to investigate the acute toxicity and the lethal concentration $\left(L C_{50}\right)$ of four herbicides, two fungicides and two insecticides to silver catfish fingerlings. All experiments were carried out in triplicates, in a static bioassay system, using commercially available pesticides. The data was analyzed through the Trimmed Spearman-Karber method available from the Environmental Protection Agency. The $96 h L C_{50}$ and 95\% lower and upper confidence limits, respectively, for the following pesticides were determined: glyphosate $\left(7.3 \mathrm{mg} \mathrm{L}^{-1} ; 6.5-8.3\right)$, atrazine $\left(10.2 \mathrm{mg} \mathrm{L}^{-1} ; 9.1-11.5\right)$, atrazine +simazine $(10.5 \mathrm{mg}$ $\left.L^{-1} ; 8.9-12.4\right)$, mesotrione (532.0mg L $\left.{ }^{-1} ; 476.5-594\right)$, tebuconazole (5.3mg L $\mathrm{m}^{-1}$; 4.9-5.7), methylparathion $(4.8 \mathrm{mg}$ $L^{-1}$; 4.3-5.3), strobulurin and triazol $\left(9.9 \mathrm{mg} \mathrm{L}^{-1} ; 8.7-11.2\right)$. Diflubenzuron was also tested and caused no fish mortality up to $1 g L^{-1}$. The toxic concentration of these pesticides to silver catfish fingerlings fell above the concentration used for application in the field and, except following accidental application or misplacing of empty recipients, it should not cause fish mortality. Nonetheless, the data obtained will be

investigados. No presente estudo, a toxicidade aguda e a concentração letal $\left(C L_{50}\right)$ de quatro herbicidas, dois fungicidas e dois inseticidas foram determinadas para alevinos de jundiás. Todos os experimentos foram conduzidos em triplicatas, utilizando-se um sistema de bioensaio estático e pesticidas comercializados localmente. Os dados foram analisados usando-se o método de Trimmed Spearman-Karber disponível na Agência de Proteção Ambiental (EUA). A $C L_{50-9 g h r}$ e os limites inferiores e superiores, com 95\% de confiança, respectivamente, para os seguintes produtos, foram: glifosato $(7,3 \mathrm{mg} / \mathrm{L} ; 6,5-$ $8,3)$, atrazina $\left(10,2 \mathrm{mg} \mathrm{L}^{-1} ; 9,1-11,5\right)$, atrazina + simazina (10,5mg L-1; 8,9-12,4), mesotrione (532,0mg L-1; 476,5-594), tebuconazol $\left(5,3 \mathrm{mg} \mathrm{L}^{-1} ; 4,9-5,7\right)$, metilparation $\left(4,8 \mathrm{mg} \mathrm{L}^{-1}\right.$; $4,3-5,3)$, estrobilurina e triazol $\left(9,9 \mathrm{mg} \mathrm{L}^{-1} ; 8,7-11,2\right)$. O diflubenzuron também foi testado, mas não causou mortalidade nos alevinos até a concentração de $1 \mathrm{~g} / \mathrm{L}$. A toxicidade dos produtos testados ficou acima das concentrações utilizadas para aplicação nas lavouras e, exceto nos casos de aplicação acidental ou despejo inadequado dos recipientes, esses produtos não poderiam causar morte de jundiás. No entanto, os dados obtidos nesses experimentos serão úteis para estudar o efeito, a longo prazo (intoxicação crônica), desses produtos, nos parâmetros hematológicos, bioquímicos, hormonais e imunológicos do jundiá e de espécies similares presentes no Sul do Brasil.
\end{abstract} useful to study the long-term effect of these products on the hematological, biochemical, hormonal and immunological parameters of silver catfish and related fish species in South Brazil.

Key words: bioassay, toxicity, pesticides, $L C_{50}$, Rhamdia quelen.

\section{RESUMO}

A toxicidade dos defensivos agrícolas para peixes é um importante fator de risco a ser avaliado. Até o presente, muitos aspectos da toxicidade dos principais defensivos agrícolas para jundiá (Rhamdia quelen) ainda não foram
Palavras-chave: bioensaio, toxicidade, pesticidas, $C L_{50}$, Rhamdia quelen.

\section{INTRODUCTION}

The silver catfish (Rhamdia quelen), a Heptapteridae fish, is one of the most widespread inhabitants of South American Rivers. In artificial pond cultures, silver catfish presents high reproduction rate

'Laboratório de Virologia e Imunologia, Hospital Veterinário, Faculdade de Agronomia e Medicina Veterinária (FAMV), Universidade de Passo Fundo (UPF), São José, 99001-970, Passo Fundo, RS, Brasil. E-mail: lckreuz@upf.br. *Autor para correspondência.

"Laboratório de Ictiopatologia, FAMV, UPF, Passo Fundo, RS, Brasil. 
and fast weight gain, mainly in the warmer months of the year (GOMES et al., 2000). This species might be used as a model to improve management of several fish species of this family.

Unfortunately, most artificial ponds used for fish culture are located close to or inside agricultural areas, or are fed with water springs that run through cultivated soil. Because of modern pest management practices, large amounts of herbicides, fungicides and pesticides are used in these areas for crop protection. In addition, some pesticides might be added directly to water to control macrophytes and predatory insects (SZAREK et al., 2000). As a result, small amounts of these products might be found in waters used for fish culture (VAN DER OOST et al., 2003). Contamination of water with large amounts of pesticides leads to fish mortality but the effects of small amounts are mostly unknown. Traditionally, survival, growth and reproduction of individuals are chosen as endpoints of the classic laboratory tests for ecotoxicity (VAN DER OOST et al., 2003). Chemicals used in agriculture may affect fish communities by altering species composition of plankton communities. In addition, exposures may also result in a disturbance of the reproductive endocrine systems (KIME et al., 1995).

To date, few data are available regarding toxicity of herbicides, insecticides and fungicides to $\boldsymbol{R}$. quelen. In irrigated rice culture commingled with silver catfish, herbicides are applied directly to the water and may affect aquatic life. The toxicity of herbicides used in irrigated rice culture has been recently evaluated (MIRON et al., 2005), and a few of these compounds were considered non-toxic for silver catfish at concentrations considered effective for weeds. In this research, the focus was to investigate the acute toxicity of pesticides commonly used in soy wheat, and corn cultures in which the product might reach water springs or ponds accidentally or through runoff of soil particles after rain (VAN DER OOST et al., 2003). Thus, the aim of this study was to determine the $\mathrm{LC}_{50}$ of commonly used agricultural products in $\boldsymbol{R}$. quelen fingerlings. These compounds were chosen according to their importance for agriculture in Southern Brazil, which is based on soybean, corn, and wheat production.

\section{MATERIALS AND METHODS}

This study was conducted between July 2004 and August 2005, at the facilities of the Universidade de Passo Fundo, Rio Grande do Sul, Brazil (28¹5'S / $52^{\circ} 24$ ”'W, $687 \mathrm{~m}$ above sea level). The fish used in the study were 60-day-old mixed-sex silver catfish fingerlings weighing between 2 and $4 \mathrm{~g}$. They were kept in 500-L fiberglass tanks up to distribution into experimental aquaria. Water exchange rates of $20 \%$ were used each day, at the same time as food wastes were suctioned from the tanks. During an acclimation period of 7 days, the fish were kept under natural photoperiod and fed two times a day (10:00 and 16:00h) at 5\% of body weight with commercial extruded food (42\% crude protein, 3,400Kcal kg-1 DE).

All water parameters were checked daily before introduction of fingerlings and up to the time the product was applied to the water. Water temperature and dissolved oxygen concentrations were measured with an YSI model 550A oxygen meter (Yellow Spring Instruments, USA). The $\mathrm{pH}$ values (Bernauer $\mathrm{pH}$ meter), total ammonia- $\mathrm{N}$ (colorimetric test), total alkalinity and hardness were also measured.

For the $\mathrm{LC}_{50}$ determinations, 210 fingerlings were uniformly distributed in $2140-\mathrm{L}$ plastic aquaria, keeping fish density below or equal to $1 \mathrm{~g} \mathrm{~L}^{-1}$, according to the Brazilian Association for Technical Rules (ABNT). Each product was tested using 5 to 6 different concentrations, with 3 repetitions each. Three aquaria were kept as control (without herbicide). Fingerlings were observed at $12 \mathrm{~h}$ intervals, for $96 \mathrm{~h}$ (acute toxicity) when the test was concluded. During the experimental period, fingerlings were not fed and water exchange was stopped.

All products used were purchased from local stores. The generic, commercial, and chemical names, and pesticide group of each product tested are shown in table 1 , and the concentrations used are shown in table 2. The concentration used for each trial was calculated using the concentration $\left(\mathrm{g} \mathrm{L}^{-1}\right)$ stated on the product's label. Before addition, each product was mixed in a small volume of water from each aquarium and then added to the water using a glass pipette. Fingerlings were then observed for $96 \mathrm{~h}$ and the mortality recorded; swimming behavior (normal, erratic swimming, lethargy) was checked, recorded and compared to the control group.

All dead fish were frozen and then shipped to the biological garbage collector. The fish that remained alive after each experiment were killed by thermal shock in ice-cold water and discarded as described above. After each toxicity trial, the water contaminated was kept for at least 30 days in fiberglass tanks and then percolated in septic ponds. After each experiment, aquaria were cleaned with running water followed by rinsing with ethanol. Before reusing, aquaria were filled with water and tested for remaining toxicity by adding silver catfish fingerlings that were observed for at least 5 days for mortality or behavioral changes. 
Table 1 - Pesticides tested for acute toxicity on Rhamdia quelen fingerlings.

\begin{tabular}{|c|c|c|c|}
\hline Generic name & Commercial name* & Chemical name & Usage \\
\hline Glifosate & Roundup & N-phosphonomethylglycine & Herbicide \\
\hline Atrazine & Atrazina & 2-chloro-4-ethylamine-6-isopropylamino-S-triazine & Herbicide \\
\hline Atrazine + Simazine & Herbimix & $\begin{array}{l}\text { 6-chloro-N,N'-diethyl-1,3,5-triazine-2,4-diamine + 2-chloro-4-ethylamine- } \\
\text { 6-isopropylamino-S-triazine }\end{array}$ & Herbicide \\
\hline Mesotrione & Callisto & [2-[4-(methylsulfonyl)-2-2 nitrobenzoyl]- 1,3 cyclohexanedione & Herbicide \\
\hline Methyl-parathion & Folidol 600 & O-O-dimethyl O-4-nitrophenyl thiophosphate & Insecticide \\
\hline Diflubenzuron & Dimilin & 1-(4-clorophenyl)-3-(2,6 diflurobenzoil) ureia & Insecticide \\
\hline Tebuconazole & Folicur & $\begin{array}{l}\text { 2-[2-(4-chlorophenyl)ethyl]-3,3-dimethyl-1-(1H-1,2,4-triazol-1-yl)buta n- } \\
\text { 2-ol }\end{array}$ & Fungicide \\
\hline Strobilurin and triazol & Opera & $\begin{array}{l}\text { Pyraclostrobin:methyl N-(2-\{[1-1(4-clorophenyl)-1h-pyrazol-3 } \\
\text { yl]oxymethyl)phenyl }\} N \text {-methoxy carbamate }\end{array}$ & Fungicide \\
\hline
\end{tabular}

* Commercial names might be trademark protected by law. All products were purchased on local stores.

The 96-h $\mathrm{LC}_{50}$ for each pesticide was calculated based on the mortality data, recorded at 12 $\mathrm{hr}$ intervals for each concentration of the product, using the Trimmed Spearman-Karber method (Version 1.5) available from the Environmental Protection Agency (USA). Comparisons of water $\mathrm{pH}$ or alkalinity among the different treatments were made by one-way analysis of variance and Tukey test. Analysis was performed using the software InsTat (Sigma), and the minimum significance level was set at $\mathrm{P}<0.05$.

\section{RESULTS}

Throughout all the trials, the water temperature averaged $22 \pm 2^{\circ} \mathrm{C}, \mathrm{pH}$ ranged from 6.2 to 7.0, dissolved oxygen ranged from 5.6 to $7.5 \mathrm{mg} \mathrm{L}^{-1}$ and total ammonia was lower than $0.5 \mathrm{mg} \mathrm{L}^{-1}$. The total hardness and alkalinity were 60 and $65 \mathrm{mg} \mathrm{CaCO}_{3}$, respectively. All values were within the acceptable limits for fish culture in pond water as reported previously (BOYD, 1982). None of the products, even at the highest concentration used, altered the water quality parameters. Lethargy, swimming at the water surface and erratic swimming (mainly vertical swimming) were the main behavioral changes observed throughout the experiment, in the presence of tebuconazole, strobilurin plus triazol, glyphosate and atrazine or atrazine plus simazine; hyper excitability was observed in fish exposed to methyl-parathion and increased abdominal volume was observed in fish exposed to atrazine or atrazine plus simazine (data not shown). Tebuconazole, at $16 \mathrm{mg} \mathrm{L}^{-1}$, caused fish death almost immediately following addition to the tank. The behavioral changes were observed with different pesticides, usually at the higher concentrations tested, but were not used to assess the effects of the products. The nominal concentration of each pesticide, the concentrations tested for toxicity, the 96-h $\mathrm{LC}_{50}$ obtained for each product, and the concentration used in the field are depicted in table 1 and 2, respectively.

\section{DISCUSSION}

In South Brazil, most fish ponds are still built in wetlands inside agricultural areas. Water contamination with agricultural pesticides is a potential threat to productivity and a major cause of fish mortality. However, water contamination with pesticides at non-lethal concentrations might pass unnoticed except for loss in productivity, which, in most cases, might be difficult to assess. In addition, there are no data on the accumulation of such chemicals in fish and how this could affect human health. Thus, it becomes necessary to determine the concentration of agricultural pesticides capable of affecting fish biochemical and physiological parameters that contribute for productivity losses. With this in mind, the 96-h LC $\mathrm{C}_{50}$ of several commonly used agricultural pesticides were determined in this study. Silver catfish fingerlings were used because this fish species is ubiquitous in rivers and ponds in South Brazil and has been intensively cultivated for commercial purposes.

The most toxic product tested was Folidol 600 (methyl-parathion, $600 \mathrm{~g} \mathrm{~L}^{-1}$; table 2), which is used in fish culture ponds to kill the aquatic larval stages of predatory insects that threaten fish larvae. The Folidol $96 \mathrm{~h} \mathrm{LC}_{50}$ was $4.8 \mathrm{mg} \mathrm{L}^{-1}$, a value similar to that found previously (MURTY et al., 1984) for Mystus cavasius (5.9 $\mathrm{mg} \mathrm{L}^{-1}$ ) and lower than that found for the mosquito fish Gambusia affins (8.4mg L $\mathrm{m}^{-1}$ ) (BOONE \& CHAMBERS, 1997). The acute effects of methylparathion were also determined for matrinxã (Brycon cephalus) in which, besides major behavioral changes, the $96 \mathrm{~h} \mathrm{LC}_{50}$ was determined at $6.0 \mathrm{mg} \mathrm{L}^{-1}$ (AGUIAR et 
Table 2 - Environmental lethal concentrations of agricultural pesticides in Rhamdia quelen.

\begin{tabular}{|c|c|c|c|}
\hline $\begin{array}{l}\text { Generic name and concentration of active } \\
\text { ingredient }\end{array}$ & Concentrations tested $\left(\mathrm{mg} \mathrm{L}^{-1}\right)$ & $\begin{array}{l}\text { 96h } \mathrm{LC}_{50}\left(\mathrm{mg} \mathrm{L}^{-1}\right)(95 \% \text { lower } \\
\text { and upper confidence interval) }\end{array}$ & $\begin{array}{l}\text { Concentration to target } \\
\text { species }\left(\mathrm{g} \mathrm{ha}^{-1}\right)\end{array}$ \\
\hline Methyl-parathion $\left(600 \mathrm{~g} \mathrm{~L}^{-1}\right)$ & $1,2,4,8,16,32$ & $4.8(4.3-5.3)$ & $300^{\mathrm{a}}$ \\
\hline Tebuconazole (200g L $\left.{ }^{-1}\right)$ & $1,2,4,8,16$ & $5.3(4.9-5.7)$ & $100^{\mathrm{a}}$ \\
\hline Glyphosate (360g L $\left.{ }^{-1}\right)$ & $2,4,8,16,32$ & $7.3(6.5-8.2)$ & $540-2160^{a}$ \\
\hline Strobilurin $\left(133 \mathrm{~g} \mathrm{~L}^{-1}\right)$ and triazol $\left(50 \mathrm{~g} \mathrm{~L}^{-1}\right)$ & $1,2,4,8,16,32$ & $9.9(8.73-11.2)$ & $50^{\mathrm{ab}} 66.5-133$ and $25-$ \\
\hline Atrazine $\left(250 \mathrm{~g} \mathrm{~L}^{-1}\right)$ & $4,8,12,16,20$ & $10.2(9.0-11.5)$ & $1000-1500^{b}$ \\
\hline Atrazine $\left(250 \mathrm{~g} \mathrm{~L}^{-1}\right)+$ Simazine $\left(250 \mathrm{~g} \mathrm{~L}^{-1}\right)$ & $1,2,4,8,16$ & $10.5(8.9-12.4)$ & $200^{\mathrm{a}} 1500-1750^{\mathrm{b}} 75-$ \\
\hline Mesotrione (480g L $\left.\mathrm{g}^{-1}\right)$ & $50,100,200,400,800$ & $532.0(476.4-594.0)$ & $144-192^{b}$ \\
\hline Diflubenzuron (250 $\mathrm{g} \mathrm{Kg}^{-1}$ ) & Up to 1000 & Not determined $^{\mathrm{c}}$ & $100^{\mathrm{b}} 60-80^{\mathrm{a}}$ \\
\hline
\end{tabular}

Concentrations of each product used in each experimental trial and 96-h $\mathrm{LC}_{50}$ values determined based on the active ingredient of each product. The concentration of each product tested was calculated based on the concentration of the active ingredient of each product as stated on the label. ${ }^{a}$ Concentration used for soybean cultures; ${ }^{b}$ concentration used in cornfields. ${ }^{c}$ Fingerlings mortality was not observed up to $1000 \mathrm{mg} \mathrm{L}^{-1}$ of diflubenzuron.

al., 2004); relevant behavioral changes were also noticed for $\boldsymbol{R}$. quelen_in the present study, mostly related to erratic swimming and hyper excitation. Taken together, the low 96-h $\mathrm{LC}_{50}$, combined with the strong behavioral changes and the fact that Folidol is frequently used directly in water, indicate that methyl-parathion is a potentially harmful compound for fish, including $\boldsymbol{R}$. quelen.

Atrazine is one of the most widely used herbicides and, because of its considerable persistence and mobility in soil and water, it is considered a common terrestrial and aquatic contaminant (OULMI et al., 1995). The 96-h $\mathrm{LC}_{50}$ of atrazine for trout embryos and larvae ranged from 0.87 to $1.11 \mathrm{mg} \mathrm{L}^{-1}$, and concentrations as low as $10 \mu \mathrm{g} \mathrm{L}^{-1}$ caused kidney damage in chronic exposed rainbow trout (OULMI et al., 1995). For Tilapia mossambicus, the atrazine 96-h $\mathrm{LC}_{50}$ was $8.8 \mathrm{mg} \mathrm{L}^{-1}$ (PRASSAD \& REDDY, 1994); chronic exposure effects were tested on Tilapia using 1/8 of this dose and several disturbances in osmotic balance of exposed fish were found. In common carp (Cyprinus carpio) the 96-h $\mathrm{LC}_{50}$ was $18.8 \mathrm{mg} \mathrm{L}^{-1}$ (NESKIVICK et al., 1993). According to these data, the $96-\mathrm{h} \mathrm{LC}_{50}$ of atrazine for $\boldsymbol{R}$. quelen $(10.2 \mathrm{mg}$ $\mathrm{L}^{-1}$ ) was similar to T. mossambicus; however, $R$. quelen was more sensitive to atrazine than $\boldsymbol{C}$. carpio_but more resistant than rainbow trout.

The 72-h LC $\mathrm{C}_{50}$ of simazine for the larval stage of Sparus aurata was $4.19 \mathrm{mg} \mathrm{L}^{-1}$ (ARUFE et al., 2004). Interestingly, the 96-h $\mathrm{LC}_{50}$ calculated for the combination of simazine plus atrazine (Herbimix ${ }^{\circledR}$ $10.5 \mathrm{mg} \mathrm{L}^{-1}$ ) was similar to that obtained for atrazine alone (10.2 $\left.\mathrm{mg} \mathrm{L}^{-1}\right)$, suggesting that in silver catfish there was no synergistic interaction between these products that could affect fingerlings survival. A more pronounced effect of atrazine or simazine alone, rather than in combination, has also been reported on olfactory cues of Salmo salar (MOORE \& LOWER, 2001). A formulation containing only simazine was not available commercially in South Brazil at the time the experiments were carried out; thus, the 96-h $\mathrm{LC}_{50}$ of simazine alone on silver catfish fingerlings has not been determined.

The 96-h $\mathrm{LC}_{50}$ determined for the glyphosate-based herbicide Roundup ${ }^{\circledR}$, in $\boldsymbol{R}$. quelen (7.3mg L ${ }^{-1}$ ) was much lower than that reported by other authors in other fish species as Lepomis macrochirus (120mg/L) and Oncorhynchus mykiss (86mg L $\mathrm{L}^{-1}$ ) (HUMBURG \& COLBY, 1989). For commercial formulations, the $\mathrm{LC}_{50}$ found varied from 3 to $197 \mathrm{mg} \mathrm{L}^{-1}$ in rainbow trout and from 13 to $33 \mathrm{mg} / \mathrm{L}$ in coho salmon (HOLTBY \& BAILLIE, 1989). For the Gambusia yucatana, the $96-\mathrm{h} \mathrm{LC}_{50}$ of glyphosate-based formulae was $17.8 \mathrm{mg} \mathrm{L}^{-1}$ (RENDÓN-VAN-OSTEN et al., 2005), a concentration closer to the values reported here. One of the reasons for the higher toxicity of commercial glyphosate-based formulas might be attributed to the presence of the surfactant (POEA), which is more toxic than glyphosate itself. The $96-\mathrm{h} \mathrm{LC}_{50}$ for isolated POEA on rainbow trout (O. mykiss) ranged from 0.65 to $7.4 \mathrm{mg}$ $\mathrm{L}^{-1}$ (GIESY et al., 2000); for commercial Roundup ${ }^{\circledR}$, the 96-h $\mathrm{LC}_{50}$ ranged from 8.7 to $27 \mathrm{mg} \mathrm{L}^{-1}$ and for pure glyphosate salt the $96-\mathrm{h} \mathrm{LC}_{50}$ ranged from 140 to $240 \mathrm{mg}$ $\mathrm{L}^{-1}$ (GIESY et al., 2000). These data show the higher toxicity of POEA, in agreement with data already reported (FOLMAR et al., 1979; TSUI \& CHU, 2003). In addition, the isolated glyphosate salt, because of its rapid degradation in water but relatively high stability in the soil, was described as secure for fish (GIESY et al., 2000). For R. quelen, Roundup ${ }^{\circledR}$ was found to have a low 96-h $\mathrm{LC}_{50}$ and more studies on active ingredients will be conducted in the near future.

Tebuconazole is a fungicide used also in plant cultures or as wood preservative against fungi 
and insects (LEBOKOWSKA et al., 2003). The $48 \mathrm{~h} \mathrm{LC}_{50}$ of tebuconazole-based formulae for Poecilia reticulata is $85 \mathrm{mg} / \mathrm{L}$ and the $96 \mathrm{hLC}_{50}$ is $45 \mathrm{mg} \mathrm{L}^{-1}$ (LEBOKOWSKA et al., 2003). This concentration is higher than that reported for $\boldsymbol{R}$. quelen $\left(4.76 \mathrm{mg} \mathrm{L}^{-1}\right.$ ), probably due to the fact that the used commercial formulation to $\boldsymbol{P}$. reticulata was less concentrated. In addition, according to previous data (LEBOKOWSKA et al., 2003), the $\mathrm{LC}_{50}$ of tebuconazole alone, for unspecified fish species, ranged from 1.6 to $8.7 \mathrm{mg} \mathrm{L}^{-1}$; thus, the $\mathrm{LC}_{50}$ of tebuconazole obtained for $\boldsymbol{R}$. quelen is within this range.

Data on acute toxicity of mesotrione, diflubenzurin and strobilurin plus triazol for fish are scarce. The $96-\mathrm{h} \mathrm{LC}_{50}$ of mesotrione for $\boldsymbol{R}$. quelen was higher than $500 \mathrm{mg} \mathrm{L}^{-1}$, a concentration higher than that achieved during field application. Mesotrione has been reported to be almost non-toxic to warm and cold-water fish (EPA, 2001) and the toxicity of strobilurin plus triazol has been studied only in rats and was considered slightly toxic by the oral route. Similarly, concentrations up to $1000 \mathrm{mg} \mathrm{L}^{-1}$ of dimilin (diflubenzurin) caused no mortality in silver catfish fingerlings during the $96 \mathrm{~h}$ exposure time.

It is worth mentioning that most differences in toxicity of the pesticides might be attributed either to the formulae used, water quality parameters or to the biochemical pathway affected by the drug and the fish species used, that might be naturally less or more tolerant to water contamination.

Regarding behavioral changes, the most prominent effect of methyl-parathion on $\boldsymbol{R}$. quelen was the induction of abnormal, erratic swimming and hyper excitability. A similar effect was also reported for $\boldsymbol{M}$. cavasius with the same product (MURTY et al., 1984). This erratic swimming occurs most likely due to acetylcholinesterase (AChE) inhibition by organophosphorus compounds, as described for several fish species (MURTY et al., 1984; AGUIAR et al., 2004; RENDÓN-VAN-OSTEN et al., 2005) including $\boldsymbol{R}$. quelen (MIRON et al., 2005). Atrazine was also reported as inducing behavioral abnormalities in Carassius auratus, most commonly erratic swimming, as also observed in the present work, after short-term exposure to sub lethal concentrations (SAGLIO \& TRIJASSE, 1998; GREYMORE et al., 2001).

Thus, because the compounds tested are widely applied around the world in soybean, wheat and corn cultures or other agricultural activities and since the Heptapteridae family represents an important fish family cultivated all over the world, the data on acute toxicity here presented might be useful to study the effects on several biochemical, hematological, immunological and physiological parameters of fish during acute or long term exposure with sub lethal doses of these products. In addition, it will provide tools for further studies considering environmental risk assessment (ERA).

\section{CONCLUSIONS}

Agricultural pesticides were toxic to silver catfish fingerlings at concentrations higher than that used against their target species; nonetheless, water run off or accidental spilling might have deleterious effect on silver catfish raised in ponds within agricultural areas. Further research on the effect of sublethal concentration of selected pesticides is being held to investigate bioaccumulation and the effect at the molecular level.

\section{BIOETHICS AND BIOSSECURITY COMMITTEE APPROVAL}

This study has been approved by the Ethic Committee Research of the Universidade de Passo Fundo $\left(\mathrm{N}^{\circ}\right.$ 630/CONEP), RS and has been developed in accordance with national and institutional guidelines for the protection of human subjects and animal welfare.

\section{ACKNOWLEDGEMENTS}

This work was supported with grants from SCIEMBRAPA 0149/2001/2 (Secretaria de Cooperação Internacional, Empresa Brasileira de Pesquisa Agropecuária) and Universidade de Passo Fundo (UPF). All undergraduate students have scientific fellowships (Deniz Anziliero, Pibic/CNPq; Monique Lorenson and Ariane Marteninghe, Pibic/UPF, Daiana Martins and Tális de Oliveira, Pivic/UPF). Leonardo Bolognesi da Silva is a MSc student and has a CNPq fellowship. CNPq granted Fellowship to LCK (300259/2003-4) and LJGB (305905/2006-6).

\section{REFERENCES}

AGUIAR, L.H. et al. Metabolical effects of Folidol 600 on the neotropical freshwater fish matrinxã, Brycon cephalus. Environmental Research, v.95, p.224-230, 2004.

ARUFE, M.I. et al. Comparative toxic effects of formulated simazine on Vibrio fishery and gilthead seabream (Sparus aurata L.) larvae. Chemosphere, v.57, p.1725-1732, 2004.

BOONE, J.S.; CHAMBERS, J.E. Biochemical factors contributing to toxicity differences among chlorpyrifos, parathion and methyl parathion in mosquito fish (Gambusia affinis). Aquatic Toxicology, v.39, p.333-343, 1997.

BOYD, C.E. Water quality management for pond fish culture. Amsterdan: NL. Elsevier Scientific, 1982. 318p.

EPA. United States Environmental Protection Agency. 2001. 7p. Pesticide fact sheet: mesotrione.

FOLMAR, L.C. et al. Toxicity of the herbicide glyphosate and several of its formulations to fish and aquatic invertebrates. 
Archives of Environmental Contamination and Toxicology, v.8, p.269-278, 1979.

GIESY, J.P. et al. Ecotoxycological risk assessment for Roundup herbicide. Review of Environmental Contamination and Toxicology, v.167, p.35-110, 2000.

GOMES, L.C. et al. Biologia do jundiá Rhamdia quelen (Teleostei, Pimelodidae). Ciência Rural, v.30, p.179-185, 2000 .

GREYMORE, M. et al. Impacts of atrazine in aquatic ecosystems. Environment International, v.26, p.483-495, 2001 .

HOLTBY, B.; BAILLIE, S. Effects of the herbicide Roundup on coho salmon fingerlings in an over-sprayed tributary of Carnation Creek, British Columbia. In: REYNOLDS, P. (Ed.) Proceedings of the Carnation Creek Herbicide Workshop. Nanaimo, BC, Forestry, Canada: Forest and Pest Management Institute, 1989. p.224-231.

HUMBURG, N.E.; COLBY, S.R. Herbicide handbook. 6.ed Champaign, IL: Weed Science Society of America, 1989. 301p.

KIME, D.E. The effects of pollution on reproduction in fish. Review Fish Biology and Disease, v. 5, p. 52-96, 1995.

LEBOKOWSKA, M. et al. Toxicity assessment of wood preservatives. Environment International, v.28, p.801-802, 2003.

MIRON, D.S. et al. Effects of the herbicides clomazone, quinclorac and metsulfuron methyl on acetylcholinesterase activity in the silver catfish (Rhamdia quelen) (Heptapteridae). Ecotoxicology and Environmental Safety, v.61, p.398-403, 2005.

MOORE, A.; LOWER, N. The impact of two pesticides on olfactory-mediated endocrine function in mature male Atlantic salmon (Salmo salar L.) parr. Comparative Biochemistry and Physiology Part B, v.129, p.269-276, 2001.
MURTY, A.S. et al. Toxicity of methyl parathion and fensulfothion to the fish Mystus cavasius. Environmental Pollution, v.34, p.37-46, 1984.

NESKIVICK, N.K. et al. Acute toxicity of atrazine to carp (Cyprinus carpio L.). Ecotoxicology and Environmental Safety, v.25, p.173-182, 1993

OULMI, Y. et al. Segment specificity of the cythological response in rainbow trout (Oncorhyncus mykiss) renal tubules following prolonged exposure to sublethal concentrations of atrazine. Ecotoxicology and Environmental Safety, v.32, p.39-50, 1995

PRASSAD, T.A.V.; REDDY, D.C. Atrazine toxicity on hydromineral balance of fish, Tilapia mossambicus. Ecotoxicology and Environmental Safety, v.28, p.313316, 1994

RENDÓN-VON-OSTEN, J. et al. In vivo evaluation of three biomarkers in the mosquito fish (Gambusia yucatana) exposed to pesticides. Chemosphere, v.58, p.627-636, 2005.

SAGLIO, P.; TRIJASSE, S. Behavioral responses to atrazine and diuron in goldfish. Archives of Environment Contamination and Toxicology, v.35, p.484-491, 1998.

SZAREK, J. et al. Effects of the herbicide Roundup on the ultrastructural pattern of hepatocytes in carp (Cyprinus carpio). Marine Environmental Research, v.50, p.263-266, 2000.

TSUI, M.T.K.; CHU, L.M. Aquatic toxicity of glyphosatebased formulations: comparison between different organisms and effects of environmental factor. Chemosphere, v.52, p.1189-1197, 2003

VAN DER OOST, R. et al. Fish bioaccumulation and biomarkers in environmental risk assessment: a review. Journal of Environmental Toxicology and Pharmacology, v.13, p.57149, 2003. 